\title{
New insights into vegetation, climate and fire history of southern Brazil revealed by a 40,000 year environmental record from the State Park Serra do Tabuleiro
}

\author{
Vivian Jeske-Pieruschka • Valerio D. Pillar • \\ Marcelo A. T. De Oliveira · Hermann Behling
}

Received: 16 August 2011/ Accepted: 22 October 2012/Published online: 20 November 2012

(C) The Author(s) 2012. This article is published with open access at Springerlink.com

\begin{abstract}
The present study reveals palaeoenvironmental changes in the coastal southern Brazilian highlands during the last 39720 в.P., by the means of pollen, charcoal and multivariate data analyses. The isolated mountain range of Serra do Tabuleiro corresponds to the southern distribution limit of many tropical plant species and is therefore sensitive to climate change. Palaeoenvironmental reconstructions from the Ciama 2 core at $860 \mathrm{~m}$ a.s.l. indicate that Campos (subtropical grassland) covered extensive areas on the highlands throughout the recorded glacial period, thus suggesting cold and dry climatic conditions. The initial development of the Atlantic rainforest occurred after the glacial period, whereas plant diversity began to increase at the beginning of the Holocene due to climate change towards warmer and wetter conditions. At about 10400 cal. B.P., the Atlantic rainforest started to move over the slopes and Campos retracted. Multivariate data analysis showed a change of vegetation dynamics after 11200 cal. B.P. with the initial development of the Atlantic rainforest continuing until the mid-Holocene. Major vegetation changes, including the further expansion of the Atlantic rainforest and the
\end{abstract}

Communicated by P. I. Moreno M.

V. Jeske-Pieruschka $(\bowtie) \cdot H$. Behling

Department of Palynology and Climate Dynamics,

Albrecht-von-Haller-Institute for Plant Sciences, University

of Göttingen, Untere Karspüle 2, 37073 Göttingen, Germany

e-mail: vjeske@uni-goettingen.de

V. D. Pillar

Departamento de Ecologia, Universidade Federal do Rio Grande do Sul, Porto Alegre, RS 91540-000, Brazil

M. A. T. De Oliveira

Departamento de Geociências, Universidade Federal de Santa Catarina, Florianópolis, SC, Brazil initial development of the Araucaria forest in the higher regions of the Serra do Tabuleiro, occurred during the late Holocene after about 3600 cal. B.P. These changes reflect higher precipitation levels without an annual dry season. Multivariate data analysis reveals a clearly directional change of vegetation dynamics corresponding to the progressive expansion of the Atlantic rainforest from 3850 to 1600 cal. B.P. A second directional change of vegetation dynamics occurred from 320 to 160 cal. B.P. (A.D. 1630 to 1790) with a further development of the Atlantic rainforest and the partial replacement of Campos by Araucaria forest and Atlantic rainforest. Thereafter, an ecosystem disturbance, which resulted in forest opening, took place. Palaeofires probably did not occur during glacial times, whereas fire events, which were probably caused by Amerindians, were common in the Serra do Tabuleiro region from ca. 10400 until 3600 cal. в.P.

Keywords Late Quaternary · Campos · Atlantic rainforest - Araucaria forest - Southern Brazilian climate · Fire history $\cdot$ Serra do Tabuleiro

\section{Introduction}

Previous palaeoenvironmental studies conducted in southern Brazil have been considerably improving the understanding of vegetation dynamics in relation to climate changes during the late Quaternary. For the southern Brazilian highlands, Campos seems to be the predominant vegetation type during glacial times when colder and drier climate conditions prevailed (Behling 1998, 2002; Roth and Lorscheitter 1993; Ledru et al. 1998; Behling et al. 2004; Leonhardt and Lorscheitter 2010). The initial Araucaria forest expansion occurred about 2850 в.P. in 
Serra dos Campos Gerais (Behling 1997) and after 2000 B.P. in Serra do Araçatuba (Behling 2007), both in Paraná state (Fig. 1c). For the highlands of Santa Catarina state, Behling (1995) proposed a first Araucaria forest expansion at about 3460 B.P. in Serra da Boa Vista and at about 2390 B.P. in Serra do Rio do Rastro. In Rio Grande do Sul, located further south than Santa Catarina, the initial Araucaria forest expansion is documented for about 3950 B.P. in Cambará do Sul (Behling et al. 2004) and after 4000 B.P. in the São Francisco de Paula region (Leonhardt and Lorscheitter 2010; Jeske-Pieruschka and Behling 2012). A marked Araucaria forest expansion is reported since about 1400 cal. B.P. in the state of Paraná (Behling 1997, 2007) and for the last 1,000 years for the highlands of the state of Santa Catarina and Rio Grande do Sul (Behling 1995; Behling et al. 2001, 2004). Although the early expansion of Araucaria forests occurred at different times, all interpretations suggest that Araucaria forest initially expanded by migrating out of gallery forests along rivers and wet areas after the mid-Holocene, when climate changed to more humid conditions. The vegetation history of the Atlantic rainforest in Volta Velha, southern Brazil is reported by Behling and Negrelle (2001). The authors documented an initial Atlantic rainforest development after 12300 B.P. as part of a successional sequence and the appearance of a dense forest after the marine regression at about 6100 в.P. for the Santa Catarina lowlands. Furthermore, Lorscheitter (2003) indicates fossil evidence of Atlantic rainforest taxa at the beginning of the Holocene at about 10000-8000 в.P. along the coastal plain and valleys of Rio Grande do Sul. More recently, Leal and Lorscheitter (2007) propose the occurrence of some Atlantic rainforest species in Serra Velha on the lower slopes of the Serra Geral, Rio Grande do Sul since 8800 в.P. However, with the exception of Behling et al. (2004), who reported environmental changes over a time frame of 42840 в.P. for the Cambará do Sul site in the southeastern highlands of Rio Grande do Sul state, no other record which reaches back as far as to the pre-last glacial maximum (LGM) period is available for the entire region of southern Brazil. Thus, our study, covering the last 39720 B.P. of vegetation, climate and fire history in Santa Catarina state, located about $175 \mathrm{~km}$ to the north from Cambará do Sul site, contributes to a better understanding of palaeoenvironmental changes and human activities in a very sensitive climatic region of South America.

Here we present new palaeoecological data from a peat core of the Serra do Tabuleiro costal mountain range. This region is covered by Campos (subtropical grassland) with some patches of Araucaria forest on the highlands and Atlantic rainforest growing in the lowlands and on the slopes. The Atlantic rainforest ecosystem is described as a hotspot of biological diversity (e.g. Myers et al. 2000; Tabarelli et al. 2005) and is known to be highly vulnerable

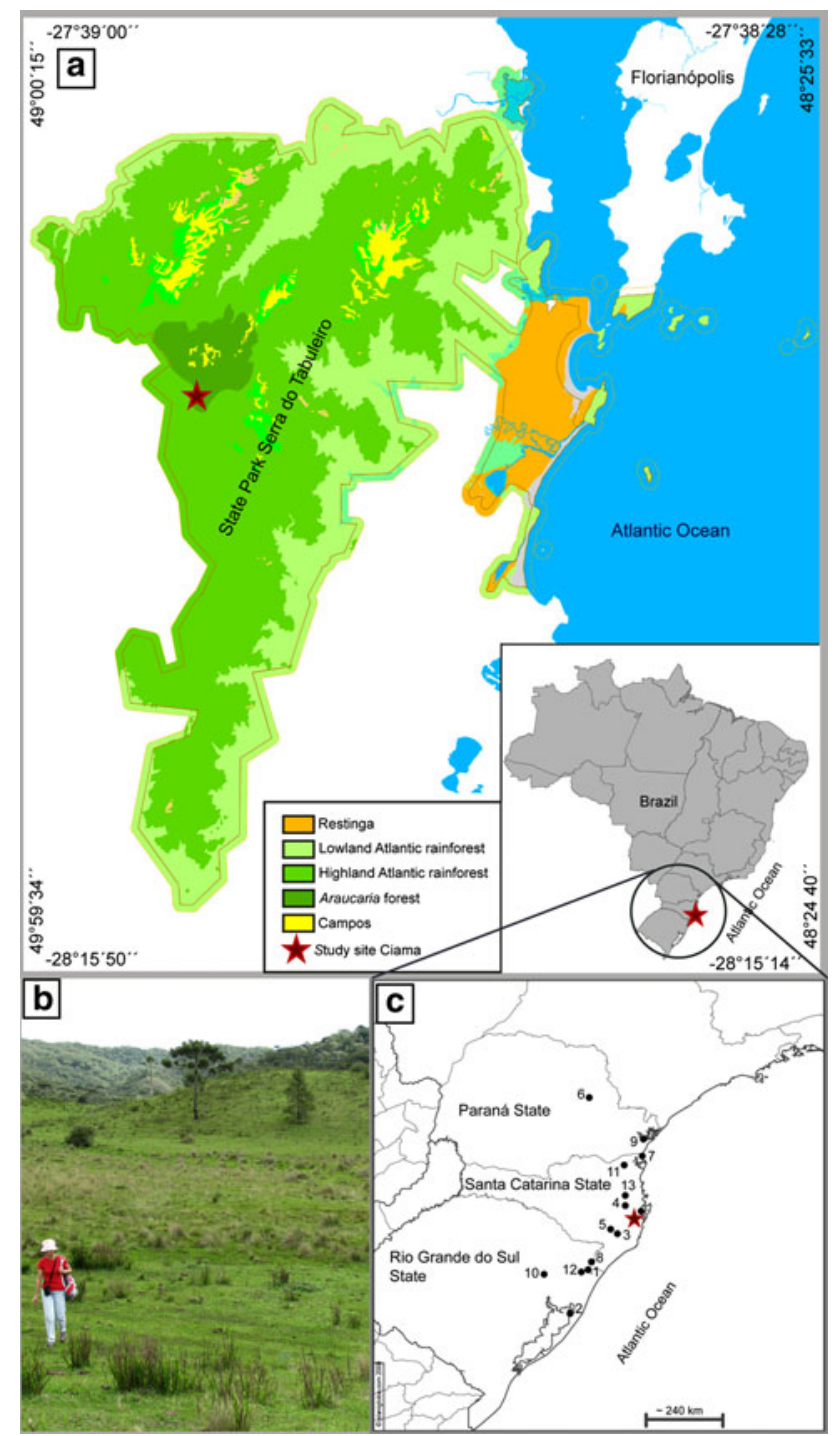

Fig. 1 a Map of the study area, showing the vegetation types of the State Park Serra do Tabuleiro. b View of the Ciama area with the peat bog surrounded by Campos with Araucaria forest and Atlantic rainforest in the background. c Map of southern Brazil with sites mentioned in the text. Palaeoecological records: (star) study site Serra do Tabuleiro 1 Aparados da Serra 2 Lagoa dos Patos 3 Serra do Rio do Rastro 4 Serra da Boa Vista 5 Morro da Igreja 6 Serra dos Campos Gerais 7 Volta Velha 8 Cambará do Sul 9 Serra do Araçatuba 10 Serra Velha 11 Campo Alegre 12 São Francisco de Paula 13 Caverna Botuverá. Sources: Vegetação Original [map]. 1:100,000. [Parque Estadual da Serra do Tabuleiro Produto Básico do Zoneamento, Estado de Santa Catarina]: Folha de referência III.1, 2000. Planiglobe Beta (www.planiglobe.com, Creative Commons Attribution 2.5 License)

to global change. Unfortunately, this ecosystem, which is very rich in species and has a high level of species endemism, is under continuous threat due to human activity since the European colonization at A.D. 1500 (e.g. Morellato and Haddad 2000). Palynological studies can offer palaeoenvironmental information, which is useful for the development of conservation and management strategies. 
The Serra do Tabuleiro represents the southern distribution limit of many tropical species and is thus an important phytogeographical divisor (Klein 1962, 1981). The species diversity of trees, shrubs, epiphytes and lianas of the Atlantic rainforest gradually decreases towards the south (Klein 1962). Therefore, new acknowledgements about the development and shifting of the Brazilian subtropical forest ecosystems are surveyed and explained in this work. Moreover, with regard to the modern discussion of global warming, we attempt to provide a basis for the prediction of subtropical vegetation responses to future climate changes.

This study is based on pollen and charcoal records covering the last 39720 years, which are analysed with the help of multivariate analysis. The aim is to reconstruct the development and dynamics of Campos, Araucaria forest and Atlantic rainforest, and the inferred climatic change in the southern Brazilian region since the pre-LGM period, for which records in this region are scanty. This study helps to answer the question if the coastal mountain range could have acted as a refugium for forest taxa during the LGM period. Another goal is to detect the effect of future climate change on the dynamics of subtropical grassland vegetation and different forest ecosystems. The significance and influence of fire and human impact during the past will be addressed as well.

\section{Regional setting}

The study area

The State Park Serra do Tabuleiro was established in 1975 and covers an area of 87,405 ha, being the largest conservation unit in Santa Catarina State (Oliveira et al. 2006). As part of the park, the investigated peat bog $\left(27^{\circ} 53^{\prime}\right.$ $48.46^{\prime \prime} \mathrm{S}, 48^{\circ} 52^{\prime} 5.33^{\prime \prime} \mathrm{W}$ ) is situated in the Ciama region (860 $\mathrm{m}$ a.s.1., Fig. 1). It is located in a small area of Campos, which is surrounded by forest. Currently, the distribution of Araucaria forest in the park is restricted to the Ciama region and its surroundings. Due to the proximity to the coast and its isolation from other mountain ranges, the site is adequate to record the development and dynamics of different ecosystems, as well as the fire history of the region.

Nowadays, the local population continues to use the land on which they lived before the establishment of the park in 1975. Forest exploitation on the Serra do Tabuleiro, mainly by logging of Araucaria angustifolia and Ocotea porosa (Klein 1981) began in the early 20th century in the course of the establishment of the Ciama sawmill. In the 1950 s, a road was constructed in the region to facilitate timber transport. The capital Florianópolis was founded by the first Portuguese settlers in the 17 th century and in the 18th century, a new wave of Portuguese settlers colonized the coast more extensively. The first German and Italian settlers arrived in the 19th century (www.angelfire.com/al/ Geografia/sc.html).

\section{Modern vegetation}

From the coastline to the upper part of the Serra do Tabuleiro at 1,200 $\mathrm{m}$ a.s.l, five different phytogeographic units can be observed (Klein 1981). In the eastern part, coastal vegetation (so-called restinga) and mangroves occur on a Quaternary sand plain. Atlantic rainforest is the dominating vegetation type on the slopes. Cloud forest grows at altitudes from 700 to $900 \mathrm{~m}$. Araucaria forest can only be found in an isolated region at higher altitudes on the western part of the Serra do Tabuleiro. Campos covers the higher altitudes of the Park, where mosaic landscape with forest patches occurs. The water supply for Florianópolis and other surrounding cities comes from streams and rivers which rise at higher altitudes. At present, large areas of natural vegetation can still be found within the park. The local vegetation of the Ciama area is secondary vegetation. It is a transition zone of Atlantic rainforest and Araucaria forest with small patches of Campos (Fig. 1). It was not clear to what extent these grassland patches were natural, as in the past, the area was used for timber exploitation by the Ciama sawmill. The Araucaria forest is composed of Araucaria angustifolia, diverse Myrtaceae and other tree species such as Calyptranthes concinna, Siphoneugena reittzii, Myrciaria tenella and Mimosa scabrella. Ocotea porosa, O. puberula, Lamanonia speciosa, Weinmannia pauliniaefolia, Drimys brasiliensis, Vernonia discolor, Piptocarpha angustifolia, Ilex spp. and Dicksonia sellowiana appear associated with Araucaria forest along the upper slopes. Characteristic for the transition between the Araucaria forest and the Atlantic rainforest are Clethra scabra, Gomidesia sellowiana, Myrsine spp., Symplocos spp., Clusia criuva, Merostachys ternata, M. speciosa and Chusquea spp. Some species from the Atlantic rainforest can also be found, such as Alchornea triplinervia, Hyeronima alchorneoides, Cryptocarya aschersoniana, Ocotea spp., Nectandra rigida, Aspidosperma olivaceum, Tapirira guianensis and Sloanea guianensis. Numerous lianas and epiphytes belonging to Bromeliaceae, Orchidaceae, Araceae, Cactaceae, as well as pteridophytes, are typical for the Atlantic rainforest ecosystem. Campos vegetation is formed by forbs and graminoids, mostly by Poaceae, Cyperaceae, Fabaceae, Verbenaceae and Asteraceae (Klein 1978, 1981). 


\section{Climate}

The climate is characterized as mesothermic (Cfa under $800 \mathrm{~m}$ a.s.l. and Cfb above $800 \mathrm{~m}$ a.s.1., Köppen) without dry season. Rainfall is uniformly distributed throughout the year with average annual precipitation varying between 1,600 and $1,800 \mathrm{~mm} /$ year. Average annual temperatures vary greatly according to the relief: lower regions and the coast have higher temperatures than the highlands, which can have temperatures below $0{ }^{\circ} \mathrm{C}$ in cold winter nights. Climate records from Florianópolis in the lowland show a January mean temperature of $24{ }^{\circ} \mathrm{C}$ and a July mean temperature of $16{ }^{\circ} \mathrm{C}$ (www.inmet.gov.br/html/clima.php). However, moderate summers and cold winters are characteristic for the highlands, while hotter and longer summers characterize the coastal area (due to subtropical latitudes) and the west (due to lower altitudes and continentality).

The study site is located in southern Brazil, which is influenced by the South Atlantic Anticyclone transporting equatorial warm and humid air masses from the tropical Atlantic Ocean over the continent during the whole year. This influence is weaker during the austral winter (JuneAugust) and more frequent during the summer (DecemberFebruary). Another atmospheric circulation, the Polar Anticyclone with dry and cold air masses, influences the climate of southern Brazil mostly during the winter. These air masses, which are formed in the Antarctic and moves across the South-American continent, provoke strong rainfall when they clash with tropical warm and humid air masses (Nimer 1989).

Precipitation anomalies are associated with El Niño Southern Oscillation (ENSO) and La Niña events. Excessive rainfall events are related to El Niño, whereas La Niña reduces rainfall in southern Brazil (Grimm et al. 1998, 2000). An excess or scarcity of precipitation in the southern coast of Brazil can also be linked respectively to periods of enhanced or weak activity of the South Atlantic Convergence Zone (SACZ) (Garreaud et al. 2009). Interannual variability of rainfall is also related to anomalies in sea surface temperature (SST), with increased or decreased precipitation respectively associated with warm or cold deviation of SST in the southwestern Atlantic Ocean (Díaz et al. 1998; Barros et al. 2000).

\section{Materials and methods}

Fieldwork and subsampling

A sediment core (169 $\mathrm{cm}$ long) was obtained from a peat bog in 2005 using a Russian corer. Each sealed $50 \mathrm{~cm}$ long core section was transported to the laboratory and stored under dark and cold conditions until it was opened for sediment description and subsampling. A total of 83 volumetric subsamples $\left(0.25 \mathrm{~cm}^{3}\right)$ was used for pollen and charcoal analysis. Subsamples were taken every $2 \mathrm{~cm}$ except between 0 and $8 \mathrm{~cm}$ core depth, where two subsamples were taken at an interval of $4 \mathrm{~cm}$. Eight subsamples were sent to the Radiocarbon Laboratory at the University Erlangen-Nürnberg, Germany, for AMS radiocarbon dating. The resulting ages were converted to calibrated calendar years before present using the software CALIB 5.0 (Stuiver and Reimer 1993). We applied the data set of SHCal04 (McCormac et al. 2004) for the ages in the Holocene period as well as for the multivariate data analysis and the one of IntCal04 (Reimer et al. 2004) for the ages in the Pleistocene period. For each calibrated age range a median probability was adopted. The age-depth model was constructed through linear interpolation between the radiocarbon ages.

Pollen and charcoal analysis

Standard pollen preparation procedures with hydrofluoric acid (HF) and acetolysis followed Faegri and Iversen (1989). One tablet of Lycopodium clavatum spores was added to each subsample to be able to calculate pollen and charcoal concentrations and accumulation rates (Stockmarr 1971). All L. clavatum spores that occur naturally in the area could be differentiated from the acetolysed $L$. clavatum marker due to the dark coloration and the wrinkled aspect of the latter. The pollen residues were mounted in glycerin gelatine and each sample was counted up to at least 300 pollen grains. Pollen and spores were identified using the reference collection available at the Department of Palynology and Climate Dynamics of the University of Göttingen and morphological descriptions by Behling (1993) and Cancelli (2008). The pollen sum (which includes all terrestrial taxa), pollen percentages and concentration were calculated and plotted in TILIA and TILIAGRAPH (Grimm 1991). The frequencies of arboreal pollen (AP), which includes pollen from tree and shrub taxa, and of non arboreal pollen (NAP), which includes pollen from herbs and grasses were plotted in the summary pollen diagram. Pollen grains of Myrtaceae are placed in the AP group. The zonation of the pollen diagrams (C2-I-IV) was based on the cluster analysis using CONISS (Grimm 1987). For the calculation we used a square root transformation for all known pollen taxa that occur in the 83 sample levels and excluded ferns, mosses, aquatics, unknown and not determined/indetermined pollen grains. The charcoal analysis was based on microscopic charred particles $(5-150 \mu \mathrm{m})$ which were counted on the pollenslides using the grid count method (Patterson et al. 1987). 
Multivariate analysis

Principal coordinates analysis ( $\mathrm{PCoA})$ of the counted pollen data set (total of 83 subsamples as units and 120 taxa as variables) was used as the ordination method and was applied to Chord distances between subsamples. All analyses were performed using the MULTIV 2.5 software (Pillar 2006). Aquatic and non-identified pollen grains, as well as all spores, except those of tree ferns, were excluded prior to analysis in order to avoid the interference of local indicators in the results. All taxa present in at least two subsamples were included. Pollen sums were square root transformed before calculating the distances to reduce the importance of dominant taxa. The ordination analysis represents past vegetation dynamics from 39720 to -55 B.P. (A.D. 2005). In addition, we analyzed the vegetation trajectory during the recorded Pleistocene period to the mid-Holocene and over the Holocene. To verify local fire events, correlations between taxa and the concentration of charred particles were performed for the late Pleistocene and Holocene periods.

\section{Results and interpretation}

\section{Lithology and chronology}

The $169 \mathrm{~cm}$ long sediment core consists of seven distinct units (Fig. 2a). At the bottom (169-142 cm), the sediment is composed of light-brown very sandy clay with organic material and small granite stones. From 142 to $70 \mathrm{~cm}$ core depth, the sediment consists of brown clay with organic material. Within this section, small amounts of sand and small granite stones occur between 142 and $120 \mathrm{~cm}$. The following interval from 70 to $45 \mathrm{~cm}$ is composed of black clay containing a few fine roots. Between 45 and $25 \mathrm{~cm}$, the sediment contains dark-brown decomposed peat containing some fine roots and from 25 to $17 \mathrm{~cm}$, the sediment contains light-brown decomposed peat containing many fine roots. The overlaying section $(17-7 \mathrm{~cm})$ consists of brown, decomposed peat rich in fine roots. In the upper part of the core $(7-0 \mathrm{~cm})$, there is a layer of weakly decomposed peat with Sphagnum sp. covering the top.

The chronology of the sediment sequence is constructed using eight AMS radiocarbon dates (Table 1). The extrapolated basal age at $168 \mathrm{~cm}$ core depth corresponds to 39720 в.P. Based on the radiocarbon dates, a continuous sedimentation with no gaps is suggested for the recorded glacial and Holocene periods. Pollen of Pinus occurs in the subsamples between 14 and $0 \mathrm{~cm}$ core depth, which thus would be after $160 \mathrm{cal}$. B.P. $(\sim$ A.D. 1790$)$ indicating a complete core until modern times. The age versus depth relationship (Fig. 2b) shows that sedimentation rates stayed relatively constant through time until $34 \mathrm{~cm}$ core depth, when the sedimentation rate increases. Around this point the sedimentological composition changes from clayey sediment to almost fully decomposed peat after $45 \mathrm{~cm}$ core depth and to weakly decomposed peat after $7 \mathrm{~cm}$ core depth. As expected, pollen concentration rates decrease significantly during this period.

\section{Description of the pollen diagram}

The pollen diagram (Fig. 3) illustrates the percentages of the dominant and most important taxa out of 200 different pollen and spore types found in the core subsamples. A summary pollen diagram (Fig. 4) represents the pollen taxa grouped into different vegetation types, as well as the charcoal data. Based on important changes in the pollen assemblages and on the result of the cluster analysis, four pollen zones have been distinguished (C2-I to C2-IV; Table 2). Pollen concentrations vary between $6.1 \times 10^{8}$ and $4.8 \times 10^{10}$ grains $/ \mathrm{cm}^{3}$ and pollen influx varies between 43,700 and $4,600,000$ grains $/ \mathrm{cm}^{2}$ year.

Zone C2-I (39720-17800 в.P.) is characterized by high percentages of NAP (69-90\%) and minor proportions of AP (6-22\%). Campos taxa are well represented, consisting primarily of Poaceae (49-75\%) and minor pollen proportions of Cyperaceae, different Asteraceae, Eryngium-type, Apiaceae, Xyris, Iridaceae and Plantago. Atlantic rainforest taxa are relatively constant (5-23\%) and are represented mostly by pollen of Myrtaceae, Weinmannia-type, Myrsine and Melastomataceae. Less frequent (1-5\%) are taxa of the Araucaria forest, represented by pollen of Ilex, Mimosa scabrella-type and Podocarpus. A single Araucaria angustifolia pollen grain was counted at $142 \mathrm{~cm}$ core depth, but single pollen grains were also registered at 168,166 and $152 \mathrm{~cm}$ core depths, as found in an additional scanning process. The tree ferns group reaches up to $8 \%$, principally due to the rise in spores of Cyatheaceae. Other Pteridophyta, with values between 4 and $15 \%$, are mainly represented by spores of Blechnum imperiale-type, Monolete psilate $<50 \mu \mathrm{m}$, Selaginella excurrenstype and Isoëtes. Moss spores are poorly represented by low percentages of Sphagnum (0-1\%). Concentrations of carbonized particles $\left(9.6 \times 10^{12}-3.225 \times 10^{14}\right.$ particles $\left./ \mathrm{cm}^{3}\right)$ and influx $\left(3.1 \times 10^{8}-1.5 \times 10^{10}\right.$ particles $/ \mathrm{cm}^{2}$ year $)$ are constantly low during this period.

In Zone C2-II (17800-9900 в.P.) the percentages of NAP increase slightly (84-90\%), while the proportions of AP show a decreasing trend (6-17\%). The Campos taxa are mainly represented by Poaceae pollen with increasing values (65-78\%). Pollen of Cyperaceae, Eryngium-type, Apiaceae, Iridaceae and Plantago decreases in abundance to $\leq 2 \%$. A slight decrease of percentages of the Atlantic rainforest group can be noted. Alchornea pollen percentages increase up to $3 \%$ at the top of this zone. Abundances of Araucaria forest taxa decrease to $0 \%$. Tree fern spores are represented by decreasing percentages, mainly by low 
Fig. 2 a Lithology and location of dated subsamples of the Ciama 2 sediment core (uncalibrated years B.P.) and b radiocarbon ages of the Ciama 2 core plotted against depth $(\mathrm{cm})$
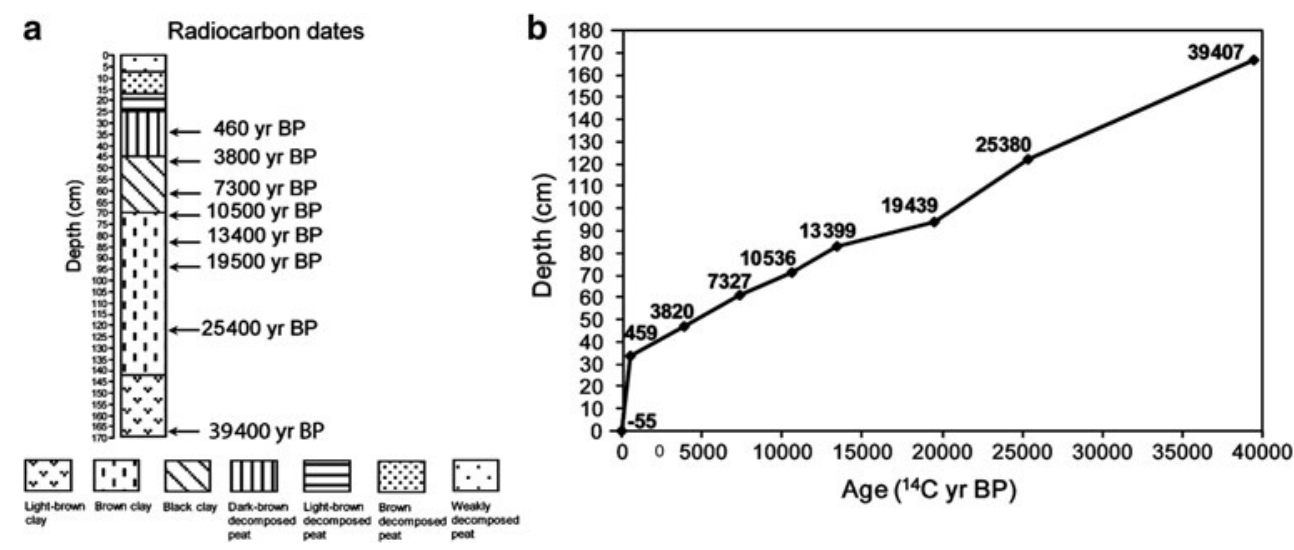

Table 1 Radiocarbon ages and calibrated ages of organic matter from the Ciama 2 core

\begin{tabular}{llllll}
\hline Lab. code & Depth $(\mathrm{cm})$ & Age (B.P.) & Age range $^{\text {a }}$ (cal. B.P.) & Med. prob. (cal. B.P.) & Calibration curve \\
\hline Erl-11255 & 34 & $459 \pm 44$ & $328-534$ & 478 & SHCal04 \\
Erl-12097 & 47 & $3820 \pm 39$ & $3981-4284$ & 4129 & SHCal04 \\
Erl-12656 & 61 & $7327 \pm 45$ & $7981-8179$ & 8092 & SHCal04 \\
Erl-11256 & 71 & $10536 \pm 63$ & $12240-12786$ & 12545 & IntCal04 \\
Erl-12657 & 83 & $13399 \pm 72$ & $15528-16341$ & 23126 & IntCal04 \\
Erl-12098 & 94 & $19439 \pm 115$ & $22661-23596$ & IntCal04 \\
Erl-12099 & 122 & $25380 \pm 152$ & Too old for calibration & & \\
Erl-11257 & 167 & $39407 \pm 681$ & Too old for calibration & & \\
\hline
\end{tabular}

${ }^{a}$ Range at standard deviation of $2 \sigma$ at $95.4 \%$ probability

values of Cyatheaceae $(<4 \%)$. The Pteridophyta group remains stable but abundances of spores of Blechnum imperiale-type and Isoëtes drop at the top of this zone. Mosses are basically represented by Sphagnum spores $(0-3 \%)$. Charcoal concentration $\left(2.0 \times 10^{13}-3.0 \times 10^{14}\right.$ particles $\left./ \mathrm{cm}^{3}\right)$ and charcoal influx $\left(3.8 \times 10^{8}-1.0 \times 10^{10}\right.$ particles $/ \mathrm{cm}^{2}$ year) continue to be low during this zone.

In Zone C2-III (9900-3300 B.P.) the proportions of NAP decrease down to $63 \%$, whereas frequencies of AP are represented by increasing values from 10 to $24 \%$. Campos taxa show a decreasing trend (80-63\%), mainly attributed to lower percentages of Poaceae pollen (65-40 \%). Pollen abundances of Asteraceae subf. Asteroideae increase up to $10 \%$ and those of Apiaceae up to $5 \%$. Eryngium-type reaches its highest values $(8 \%)$ in this zone. A marked increase of abundances of Atlantic rainforest taxa from 12 to $28 \%$ can be noted. This is mainly due to the increase in Weinmannia-type pollen to $14 \%$ at the top of this zone. Pollen percentages of Myrsine, Melastomataceae and Alchornea and, with lower values, of Moraceae/Urticaceae, Celtis and Trema-type also increase. Myrtaceae pollen frequencies slightly decrease (4-1\%). Taxa of the Araucaria forest $(<2 \%)$ are much less frequent. Tree fern taxa increase to $7 \%$, with higher proportions of Cyatheaceae and lower frequencies of Nephelea setosa and Dicksonia sellowiana. The group of Pteridophyta is well represented with values between 6 and $16 \%$, mainly composed of spores of Monolete psilate $<50 \mu \mathrm{m}$. Spore abundances of Blechnum imperiale-type increase up to $7 \%$ at the top of this zone. Abundances of spores of Selaginella excurrenstype decrease strongly (7-0\%). Moss proportions increase slightly up to $5 \%$, represented by spores of Sphagnum and Phaeoceros laevis (not shown in the diagram). Values for concentrations $\left(3.3 \times 10^{14}-1.15 \times 10^{15}\right.$ particles $\left./ \mathrm{cm}^{3}\right)$ and influx $\left(1.1 \times 10^{10}-4.5 \times 10^{10}\right.$ particles $/ \mathrm{cm}^{2}$ year $)$ of carbonized particles increase markedly in this zone.

Zone C2-IV (3300 B.P. to the present) is divided into two subzones (IV-a and IV-b). This zone shows a further decrease in NAP down to minimum proportions of $26 \%$, but they recover higher to the top of the zone reaching values of $48 \%$. AP increases markedly with values ranging between 26 and $68 \%$. A strong decrease from 61 to $26 \%$ in Campos taxa is mostly reflected by the decrease of Poaceae pollen (31-7\%). Abundances of Cyperaceae pollen increase markedly compared to the previous zone and reache values of $21 \%$. Pollen frequencies of the Heliantheae-type also increase (up to $8 \%$ ) whereas Apiaceae pollen percentages decrease strongly, reaching a maximum value of $1 \%$. Pollen abundances of Eryngiumtype decrease continually from $6 \%$ at the first part of the zone to $0 \%$, but they increase up to $3 \%$ towards the top of the core. Abundances of Atlantic rainforest taxa show a 


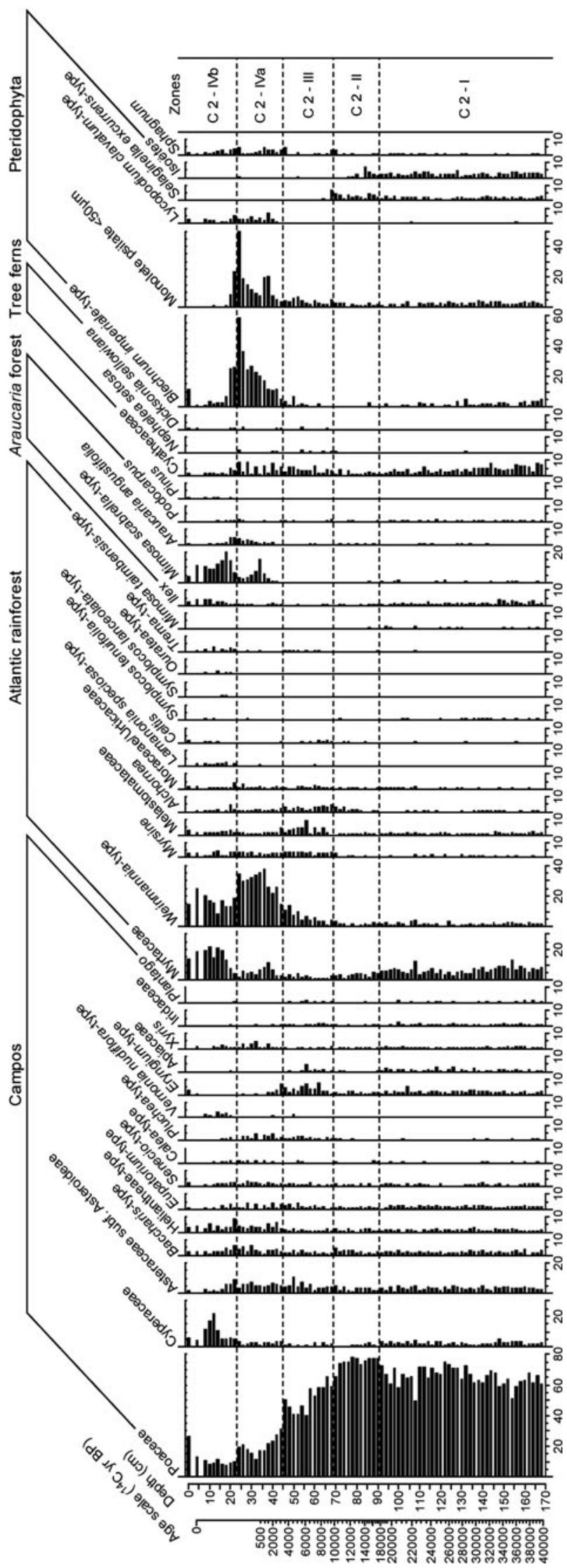

4 Fig. 3 Pollen diagram for the Ciama 2 core, showing percentages based on the total pollen sum of the major and significant taxa, grouped into Campos, Atlantic rainforest, Araucaria forest, Tree ferns and Pteridophyta

further increase, reaching values between 30 and $54 \%$, as pollen percentages of Myrtaceae (2-22\%) and Weinmannia-type $(8-37 \%)$ rise. Moraceae/Urticaceae pollen frequency increases again slightly (4\%), while pollen percentages of Melastomataceae and Alchornea decrease. The Araucaria forest group shows a notable increase from 1 to $24 \%$, mostly due to values of Mimosa scabrella-type pollen (0.3-20\%). Percentages of Araucaria angustifolia pollen increase considerably up to $4 \%$, but decline towards to the top of this zone. Abundances of tree fern taxa increase up to $10 \%$, but decrease further to a minimum of $1 \%$. Pteridophyta spores reach very high proportions of up to $121 \%$ at $24 \mathrm{~cm}$ depth, but decrease strongly to a minimum of $5 \%$ at $4 \mathrm{~cm}$ core depth. Spores of Lycopodium clavatum-type $(0-6 \%)$ increase, whilst spores of Selaginella excurrens-type and Isoëtes are only found sporadically during this period. Mosses are mainly represented by Sphagnum spores $(0.3-5 \%)$. Concentration $\left(5.0 \times 10^{14}\right.$ particles $\left./ \mathrm{cm}^{3}\right)$ and influx $\left(2.0 \times 10^{10}\right.$ particles $/ \mathrm{cm}^{2}$ year $)$ of carbonized particles are very high in the lowermost part of the zone and decrease significantly towards the top of the core $\left(2.0 \times 10^{12}\right.$ particles $/ \mathrm{cm}^{3}$ and $1.5 \times 10^{9}$ particles $/ \mathrm{cm}^{2}$ year, respectively).

The subzone, C2-IVa (3300-290 в.P.), shows an increase in Baccharis type, Eupatorium type, Senecio type, Calea type, Plucheae type and Xyris pollen frequencies. The opposite trend can be observed for the following subzone C2-IVb (290 B.P. to the present). Cyperaceae pollen abundances increase markedly compared to the previous subzone (up to $21 \%$ ). Pollen percentages of Myrtaceae (2-11\%) increase again during the subzone C2$\mathrm{IVa}$ and reach maximum values of $22 \%$ in the next subzone C2-IVb. Abundances of Weinmannia-type pollen increase strongly with proportions up to $37 \%$ at C2-IVa, but decrease to $8 \%$ in the following subzone. Compared to the previous subzone, Lamanonia speciosa-type, Celtis, Symplocos lanceolata-type, Ouratea-type and Trema-type pollen occur with higher proportions in subzone C2-IVb. Ilex and Mimosa scabrella-type pollen percentages increase in subzone C2-IVa and continue to increase in subzone C2-IVb. Podocarpus pollen frequencies decrease to $0 \%$ in subzone C2-IVb. Pinus pollen reaches amounts of $1 \%$ at the top of the core. Cyatheaceae spores decrease in abundance compared to the previous subzone. Proportions of Blechnum imperiale-type (up to $58 \%$ ) and Monolete psilate $<50 \mu \mathrm{m}$ (up to $50 \%$ ) reach high values in subzone C2-IVa, but decrease significantly in the subsequent subzone. 


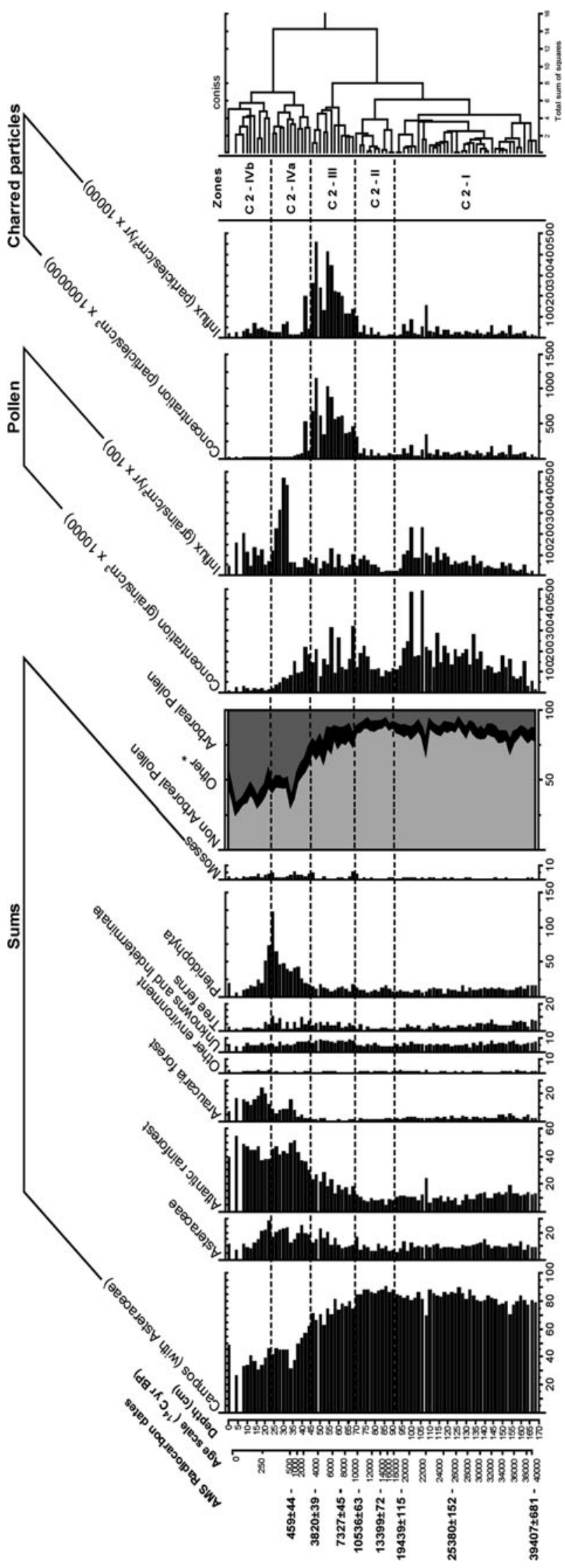

4 Fig. 4 Summary pollen percentage diagram, including pollen and charcoal concentration as well as pollen and charcoal influx and the cluster analysis dendrogram of the Ciama 2 peat bog. * Other includes pollen grains from taxa that can have different growth forms (tree, shrub, herb or liana) as well as all unknown and indeterminate pollen grains counted in all depth levels of the core

Multivariate analysis

The complete trajectory of pollen composition changes over the last 39720 в.P. is shown in the ordination diagrams (Fig. 5a, b). Axes 1 and 2 explain $58 \%$ of the total variation in the data set with 120 taxa and 83 subsamples. A random phase, with slight changes in vegetation occurs during the glacial period until 12680 в.P. (13470 cal. в.P.) with Campos as the dominating vegetation type in the system. Non-directional changes in pollen composition dynamics at the small temporal scale and a directional trend at the large scale during the end of the Pleistocene (12680 в.P. or 13470 cal. в.P.) until the midHolocene (3560 в.P. or 3850 cal. в.P.) can be observed in Fig. 5b. The replacement of the initially predominant Campos (Fig. 5a, on the right-hand side) by forest vegetation (Fig. 5a, on the left-hand side) occurs after $3850 \mathrm{cal}$. B.P., when Atlantic rainforest and Araucaria forest expands. Changes in the pollen composition along a time trajectory from 39720 until 3560 в.P. (3850 cal. в.Р.) are depicted on a separate ordination (Fig. 5c, d), in which the two main axes account for $35 \%$ of the total variation. During the period from 39720 until 12680 B.P. (13470 cal. в.P.), corresponding to the pollen zones C2-I and II, the system is dominated by Campos, represented primarily by Poaceae (Fig. 5c). Some taxa belonging to the Araucaria forest, like Ilex and Myrtaceae, are present, but decrease slightly during this period. Myrtaceae may also correspond to species that occur in the Campos vegetation, which can be seen on the right-hand side in Fig. 5c, together with the groups of Cyperaceae and Apiaceae. Subsequent to phases of randomness, an evident change in the vegetation dynamics occurs after 10780 в.P. (11200 cal. в.P.), corresponding to the pollen zone C2-III. The vegetation is characterized by increased quantities of forest taxa, such as Alchornea, Myrsine, Weinmannia and Melastomataceae, which represent the Atlantic rainforest (Fig. 5c, on the left). Another ordination exploring the period of 8930 B.P. (9510 cal. в.P.) to -55 в.P. (A.D. 2005) (Fig. 5e, f) reveals the vegetation dynamics over the Holocene period and towards the end corresponds to the pollen zone C2-IV. The main ordination axes account for 47.6 and $12.6 \%$, respectively, for the first and second axes. Three phases of strong directionality of vegetation change occur. The first significant directional change in pollen composition appears from 3560 until 1490 в.P. (3850 until 1600 cal. в.P.), 
Table 2 Pollen zones of the Ciama 2 core, showing the depth, the converted radiocarbon ages and the number of subsamples for each pollen zone

\begin{tabular}{lllll}
\hline Zone & $\begin{array}{l}\text { Depth } \\
(\mathrm{cm})\end{array}$ & $\begin{array}{l}\text { Age range } \\
\text { (B.P.) }\end{array}$ & $\begin{array}{l}\text { Age range } \\
\text { (cal. B.P. })\end{array}$ & $\begin{array}{l}\text { No. of } \\
\text { subsamples }\end{array}$ \\
\hline C2-I & $168-91$ & $39720-17800$ & & 39 \\
C2-II & $91-69$ & $17800-9900$ & $21200-10400$ & 11 \\
C2-III & $69-45$ & $9900-3300$ & $10400-3600$ & 12 \\
C2-IVa & $45-23$ & $3300-290$ & $3600-300$ & 11 \\
C2-IVb & $23-0$ & $290--55$ & $300--55$ & 10 \\
\hline
\end{tabular}

when the vegetation changes from predominantly open Campos (Fig. 5e, on the right), to a more forested one (Fig. 5e, on the left). The Atlantic rainforest expands, mostly represented by Weinmannia, whereas the Araucaria forest starts to develop, as it is reflected by Araucaria angustifolia pollen grains (Fig. 5e). The second directional change follows a random phase and takes place from about 310 until 160 B.P. (A.D. 1630-1790). During this phase, a further development of the Atlantic rainforest and the Araucaria forest occurs, which replace in part the Campos. This is represented by the taxa Lamanonia speciosa, Myrtaceae, Symplocos tenuifolia, S. lanceolata and Ouratea (Fig. 5e, on the left). Also, Araucaria forest is well represented by taxa such as Mimosa scabrella, Ilex an A. angustifolia. From 5 to -55 B.P. (A.D. 1940 to 2005), subsequent to the spatial expansion of the forest, a sharp change in pollen composition takes place, with a tendency towards a pollen composition of Campos vegetation.

Environmental reconstruction based

on the palaeoecological record

A grassland landscape predominated in the southern Brazilian highlands throughout the pre-LGM and LGM period from 39720 B.P. until 21200 cal. B.P. (zone C2-I). The vegetation was mainly composed of grasses (Poaceae) and different forbs of the Asteraceae family, but also of Cyperaceae, Apiaceae and other plants characteristic of grassland ecosystems. Some species of Myrtaceae, placed in the Atlantic rainforest group, probably belonged to the grassland vegetation during the recorded last glacial. They might have been shrub species (e.g. Campomanesia spp.) that grew in open grassland vegetation at this time. The multivariate analysis of the pollen data indicates a predominance of Campos taxa during the palaeovegetational trajectory spanning over glacial times (from 39720 to 12680 B.P. or 13470 cal. B.P.; zone C2-I-II). As indicated by a random phase, only small changes in pollen composition that therefore do not reflect marked changes in vegetation dynamics occurred during the last glacial period. Steady cold climatic conditions at this time may have only produced small-scale compositional changes
Table 3 Abbreviations of the pollen taxa shown in the ordination diagrams

\begin{tabular}{ll}
\hline Abbreviation & Pollen and spore taxa \\
\hline Alcho & Alchornea \\
Apiac & Apiaceae \\
Arauc & Araucaria angustifolia \\
Astsu & Asteraceae subf. Asteroideae \\
Celti & Celtis \\
Cyath & Cyatheaceae \\
Cype & Cyperaceae \\
Dicks & Dicksonia sellowiana \\
Eryng & Eryngium-type \\
Helia & Heliantheae-type \\
Holo & Holocheilus-type \\
Ilex & Ilex \\
Irida & Iridaceae \\
Lama & Lamanonia speciosa-type \\
Melas & Melastomataceae \\
Misca & Mimosa scabrella-type \\
Myrsi & Myrsine \\
Myrta & Myrtaceae \\
Nephe & Nephelea setosa \\
Ourat & Ouratea-type \\
Oxali & Oxalis-type \\
Plant & Plantago \\
Pluch & Plucheae-type \\
Poac & Trixis-type \\
Symla & Ternonia nudiflora-type \\
Symte & \\
Tetru & Tretrorchidium rubrivenium \\
Trema & Trixi \\
Vernu & Weinm \\
\hline
\end{tabular}

in the highlands. During the pre-LGM and LGM period, the Atlantic rainforest was represented by low frequencies of Weinmannia, Myrsine, Melastomataceae, Alchornea, Moraceae/Urticaceae, Celtis, Symplocos tenuifolia and Mimosa taimbensis. Small populations of arboreal taxa probably occurred on the slopes of the mountain range at lower elevations or even formed small gallery forests along rivers or streams in the lowland, thereby creating refugia. It might be possible that these taxa existed in deep valleys of the Serra do Tabuleiro where humidity was retained. Some (sub-) tropical forest species such as Roupala, Drimys brasiliensis, Mimosa taimbensis, Sebastiania commersoniana (not shown in the pollen diagram) and Symplocos lanceolata were not present during the LGM period. Other sensitive arboreal species such as Alchornea and Myrsine were represented by diminished abundances, sometimes with only one pollen grain in 

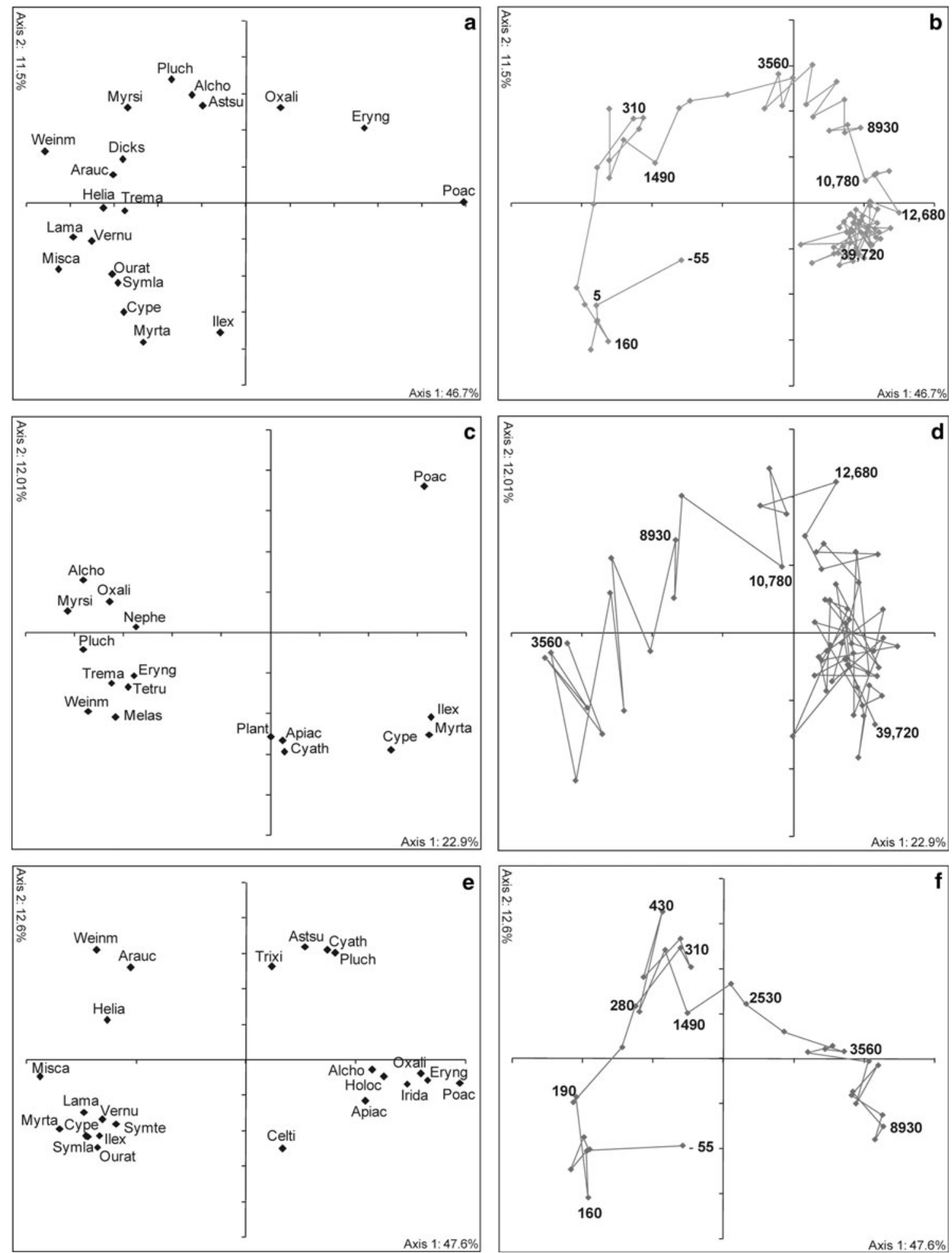

Fig. 5 Ordination diagrams based on principal coordinate analysis (PCOA) applied to chord distances between sampling units from the Ciama 2 core. Pollen data were previously square-root transformed. The complete vegetation trajectory for the last 39720 B.P. is mapped in the diagrams a, b with 83 sampling units and 120 taxa including counted pollen types and tree fern spores. Sampling units are identified by age (radiocarbon years). Other separated ordinations using the same method map the trajectory over the Pleistocene until the mid-Holocene in $\mathbf{c}$, d, with 62 sampling units and 102 taxa, and over the complete Holocene in e, f, with 33 sampling units and 87 taxa. Only taxa with the highest correlation $(-0.5 \leq r \geq 0.5)$ are shown in positions proportional to their correlation level to each ordination axis in $\mathbf{a}, \mathbf{c}$ and $\mathbf{e}$. Taxa abbreviations are shown in Table 3 
Table 4 Pollen taxa with the highest positive or negative correlations to charcoal concentration during the Pleistocene and Holocene period. All pollen taxa found in at least $50 \%$ of the subsamples were used for the analysis

\begin{tabular}{|c|c|c|c|}
\hline \multicolumn{2}{|l|}{ Pleistocene 39720-10200 в.Р. } & \multicolumn{2}{|c|}{ Holocene 9600 в.P. until present } \\
\hline Таха & $r$ & Taxa & $r$ \\
\hline Weinmannia-type & 0.57396 & Poaceae & 0.75412 \\
\hline Alchornea & 0.36713 & Eryngium-type & 0.65964 \\
\hline Asteraceae subf. Asteroideae & 0.35346 & Melastomataceae & 0.50486 \\
\hline Baccharis-type & 0.33598 & Cyperaceae & -0.43453 \\
\hline Myrsine & 0.27903 & Blechnum imperiale-type & -0.45904 \\
\hline Holocheilus-type & 0.27424 & Araucaria angustifolia & -0.46249 \\
\hline Iridaceae & 0.25451 & Ilex & -0.4772 \\
\hline Blechnum imperiale-type & -0.34302 & Lamanonia speciosa-type & -0.48713 \\
\hline \multirow[t]{5}{*}{ Poaceae } & -0.40661 & Heliantheae-type & -0.50711 \\
\hline & & Myrtaceae & -0.5557 \\
\hline & & Lycopodium clavatum-type & -0.58425 \\
\hline & & Weinmannia-type & -0.58822 \\
\hline & & Mimosa scabrella-type & -0.61206 \\
\hline
\end{tabular}

permitted a forest development, which is indicated by a large-scale directional trend during the end of the Pleistocene $(13470 \mathrm{cal}$. в.P.) until the mid-Holocene $(3850 \mathrm{cal}$. B.P., Fig. $5 \mathrm{c}, \mathrm{d}$ ). This directional change was characterized by the increase in forest taxa such as Alchornea, Myrsine, Weinmannia and Melastomataceae mentioned above, thus suggesting the expansion of Atlantic rainforest.

From 3600 cal. B.P. until the present (zone C2-IV), a continuous development/expansion of Atlantic rainforest took place, and Araucaria forest began to develop and expand as well. At this time, the study bog was covered by Sphagnum and Blechnum imperiale. An evident directional change of vegetation dynamics happened from 3850 to 1600 cal. B.P. when Atlantic rainforest continued to expand mostly due to Weinmannia and Myrtaceae, while the Araucaria forest group started to develop mainly with the pioneer taxa Mimosa scabrella and Araucaria angustifolia (Fig. 5e, f). Forest development and expansion was probably related to increased moisture levels during this period. The establishment of a forest environment throughout the mid/late Holocene (3600-300 cal. B.P.; subzone C2-IVa) is indicated by the decrease of proportions of Poaceae, some Asteraceae, Apiaceae, Eryngium and other Campos taxa, whereas Myrtaceae and Weinmannia greatly increased. Araucaria forest began to develop at approximately 2160 cal. B.P. and reached its maximum expansion in the study area after 300 cal. B.P. (A.D. 1650).

Major changes in forest composition occurred during the last 360 years (subzone $\mathrm{C} 2-\mathrm{IVb}$ ). After the change of the predominant Campos vegetation to a forest system, another directional change in vegetation dynamics occurred from 320 to 160 cal. B.P. (A.D. 1630 to 1790). During this period, Atlantic rainforest and Araucaria forest expanded further, thereby replacing Campos. This can be observed by the increased abundances of Lamanonia speciosa, Myrtaceae,

B.P. Better climatic conditions with higher humidity 
Symplocos tenuifolia, S. lanceolata, Ouratea, Mimosa scabrella, Ilex and Araucaria angustifolia (Fig. 5e). Later, ecosystem disturbance occurred, resulting in forest opening. This disturbance is indicated by the increase of Trema and Mimosa scabrella, coinciding with the decrease of Araucaria angustifolia and Podocarpus. Both Trema and Mimosa scabrella are known as pioneer species that establish after disturbance, thus representing forest exploitation by European settlers and logging in the last years. An abrupt decrease of Blechnum imperiale after 260 cal. B.P. (A.D. 1690) also indicates bog disturbance. From A.D. 1940 to 2005, a strong directional phase in vegetation dynamics revealed by changes in pollen composition indicates a trend of Campos species returning to the Ciama area (Fig. 5e, f). The higher occurrence of Poaceae at the top of subzone C2-IVb may indicate the opening of the forest due to human activity.

\section{Palaeofires}

Two main phases could be distinguished in the curves of charcoal concentration and influx based on the counted charcoal particles. The first phase, with relatively constant low proportions of microcharred particles, corresponds to the recorded last glacial period. The second phase is marked by a rising trend of microcharcoal fragments starting about $10360 \mathrm{cal}$. B.P. Higher concentrations of charred particles until 3570 cal. B.P suggests that fire was very common in the region during this time. Fire events continued to be common in the Serra do Tabuleiro during the late Holocene, as indicated by high frequencies of charred particles for the last centuries. This cannot be easily recognized in the charcoal concentration and influx curves, as there is a dissimilar time resolution of about 500 years from the $34 \mathrm{~cm}$ depth in the core upwards in comparison to the millennial timescale of the deeper samples, which expressed slow sedimentation rates.

Results of unexpected correlations between pollen taxa and charcoal concentration (Table 4) during the Pleistocene (zone C2-I and C2-II) support the assumption that fire was almost absent during glacial periods on the Serra do Tabuleiro. Forest taxa, such as Weinmannia, show a highly positive correlation with charcoal concentration, while Poaceae as a Campos taxon and Blechnum imperiale as a fern that grows in peat bogs are negatively correlated to charcoal concentration. On the other hand, results of correlation analyses between pollen taxa and charcoal concentrations during the Holocene (zone C2-III and C2-IV) show a strong positive correlation of Poaceae with charred particles, while forest taxa such as Mimosa scabrella, Weinmannia and Myrtaceae show a strong negative correlation with charcoal concentration (Table 4). These results indicate that fires occurred locally or regionally during the Holocene.

\section{Discussion}

Late quaternary vegetation dynamics

During the recorded glacial period (39720 в.P. to $10400 \mathrm{cal}$. B.P.), grassland vegetation, dominated by Poaceae, covered the highlands of southern Brazil. The low representation of $\mathrm{AP}$, together with the high quantity of grasses in the pollen record, indicates that cold and dry climatic conditions prevailed in this region during this period. Roth and Lorscheitter (1993) proposed drier conditions before the Holocene for the Aparados da Serra region in the southern Brazilian highlands based on a reduced forest cover and an expansion of grassland. Several authors agree that cold and dry climatic conditions prevailed in southern Brazil during the last glacial period (e.g. Behling 1998, 2002; Leonhardt and Lorscheitter 2010; Jeske-Pieruschka and Behling 2012). Additional information on a late Pleistocene dry period comes from a geomorphic study of the northern highlands of Santa Catarina state (Campo Alegre, Oliveira et al. 2008). According to Behling et al. (2004), climate in the southern Brazilian highlands was dry and cold during the pre-LGM, but even drier and colder during the LGM. These results are in accordance with ours, which demonstrate colder and drier climatic conditions during the LGM in comparison to the pre-LGM on the Serra do Tabuleiro. With respect to palaeoclimate, Behling and Negrelle (2001) propose an annual average cooling of $5-7{ }^{\circ} \mathrm{C}$ for the LGM period in the southern Brazilian lowlands. According to our results, a treeless landscape continues to dominate the southern region of Brazil under a continuously cold and dry climate during the late glacial period. Other palaeoecological studies have confirmed drier conditions for the highlands of southern Brazil throughout this period (e.g. Behling 1995, 1997, 2007).

The Serra do Tabuleiro could have acted as a refugium for forest taxa during the LGM. The proximity to the Atlantic Ocean could have provided milder climatic conditions that would have favored the survival of some trees during this period. Some orographically protected areas, such as deep valleys, where a microclimate with higher levels of humidity favored tree survival under regionally dry conditions, could be hypothesized as refugia. However, the very low proportions of AP including (sub-) tropical sensitive tree species as Alchornea and Myrsine among others, suggested that the coastal mountain range of Serra do Tabuleiro was not a glacial refugium for Atlantic rainforest taxa during the LGM. Furthermore, if the Serra do Tabuleiro had been a glacial refugium for forest taxa, then the small arboreal populations existing there up to this period would have expanded rapidly since the 
beginning of the Holocene when moister and milder climatic conditions arose. The conifers Araucaria angustifolia and Podocarpus had probably been present as small populations in protected valleys or on slopes at lower elevations of the Serra do Tabuleiro during the last glacial period. Taking Araucaria angustifolia as an indicator species for moist and cold forest, since it can neither tolerate temperatures lower than $-10{ }^{\circ} \mathrm{C}$ nor an annual precipitation lower than $1,400 \mathrm{~mm}$ or a marked dry season (Hueck 1966), climate was cold on the Serra do Tabuleiro during the last glacial. Lower precipitation and higher temperature levels can affect Araucaria angustifolia growth (Silva et al. 2009). According to Leonhardt and Lorscheitter (2010), a warmer climate affects the reproductive capacity of Araucaria forest taxa.

\section{Holocene vegetation dynamics}

The Atlantic rainforest that characterizes the region today started to move from the lowland over the slopes in the early Holocene. Our results indicate that between 10400 and 3600 cal. B.P., due to warmer and wetter climatic conditions, the Atlantic rainforest probably extended over the coastal slopes of the Serra do Tabuleiro. However, the amount of Poaceae pollen remained high during late Holocene despite the expansion of forest. Thus, the interpretation that a mosaic of natural grassland and forest remained during late Holocene at the studied site is compatible with our pollen record. Indeed, other studies have indicated that grassland vegetation continued to dominate the landscape of the southern Brazilian highlands. It would be reasonable to interpret that prolonged phases of drought continued to prevail in the region despite of milder and moister conditions since the early Holocene. Further, the occurrence of fire during the Holocene may have restricted forest expansion over grassland (Oliveira and Pillar 2004; Blanco personal communication). Ledru et al. (2009) stated that, although changes in insolation are the most important climatic factor controlling rainforest dynamics in the southern tropics, changes in precipitation rates and/or seasonality greatly affect the tropical rainforest. A pollen profile from São Francisco de Paula, on the eastern plateau of southernmost Brazil (Serra Geral), indicates that temperature and moisture increased at the beginning of the Holocene (Leonhardt and Lorscheitter 2010). The pollen record from Serra Velha on the lower slope of the Serra Geral about $330 \mathrm{~km}$ south of the Ciama 2 site shows the occurrence of Atlantic rainforest taxa at about 8800 and 5000 B.P., indicating the migration of tropical species from east to west since the early Holocene (Leal and Lorscheitter 2007). However, Behling (1995) demonstrated for the highlands of Santa Catarina state that Campos vegetation continued to prevail until ca. 1000 B.P. on Morro da Igreja and Serra do Rio do Rastro, while an expansion of Atlantic rainforest taxa followed by Araucaria forest occurred at the beginning of the Holocene in the Serra da Boa Vista. The latter site is located $50 \mathrm{~km}$ inland from the Atlantic Ocean and $\sim 35 \mathrm{~km}$ from the Ciama 2 site, which in turn is situated just $25 \mathrm{~km}$ away from the coast. The proximity of these sites to the Atlantic Ocean may have provided higher moisture, as they have been influenced by the warm and humid Tropical Atlantic Air Mass since the early Holocene. Observations of wetter climatic conditions in the lowlands and on the Atlantic slopes of the southern Brazilian highlands since the beginning of the Holocene come from Behling (1998). In the southern Atlantic lowlands, Atlantic rainforest started to develop after 12300 B.P. as a part of a successional sequence. However, a dense forest did not become established until after the marine regression at about 6100 B.P. (Behling and Negrelle 2001). A wet climate has been recorded since about 4000 B.P. for the southernmost Brazilian coastal lowlands (Lagoa dos Patos, Cordeiro and Lorscheitter 1994). These results differ from Behling (1998) and Ledru et al. (1998) who suggest dry climatic conditions for southern Brazil during the early/mid Holocene. Other studies report drier conditions and a longer annual dry season for the southern Brazil highlands during the early and mid-Holocene (Behling 1997, 2002, 2007; Behling et al. 2001, 2004). However, these studies cover sites that are further inland than Ciama 2. Our results from the Serra do Tabuleiro, which is located much closer to the Atlantic Ocean, indicate that humidity levels rose gradually throughout the Holocene.

Forest establishment during the mid/late Holocene was related to increased moisture levels during this period. A comparison with a high-resolution oxygen and carbon stable isotope record from cave calcite from Caverna Botuverá, at a distance of $80 \mathrm{~km}$ from the Ciama 2 site, reveals that the local temperature can be affected by the summer monsoonal precipitation as well as by winter extratropical circulation patterns (Cruz et al. 2005, 2006). Negative $\delta^{13} \mathrm{C}$ and $\delta^{18} \mathrm{O}$ values in this speleothem record indicate that increased rainfall coincided with a marked forest expansion across the Serra do Tabuleiro during the mid-Holocene. From 3600 cal. B.P. to the present, the Atlantic rainforest continues to develop/expand while the Araucaria forest began to develop initially at about 2160 cal. B.P., reaching its maximum expansion after $300 \mathrm{cal}$. B.P. (A.D. 1650). Hence, a pronounced development of the Araucaria forest happened much later in the Serra do Tabuleiro than in the Serra Geral further south, and just within the northwestern part of the park. The isolated occurrence of Araucaria forest and its very late expansion despite favorable climatic conditions suggest that the Serra do Tabuleiro was not a refugium for Araucaria forest taxa during glacial times.

Pollen data from other sites in the southern Brazilian highlands agree in suggesting that forest expansion started in the mid-Holocene and reached its expansion maximum after 1500 cal. B.P. (Behling 1995, 1997, 2007; Behling et al. 2004; Jeske-Pieruschka and Behling 2012). However, as shown in our study, the Atlantic rainforest began to move from the 
lowland upwards across the slopes under milder and wetter conditions in the early Holocene. A continuous forest development/expansion of the Atlantic rainforest and a first development of the Araucaria forest is reported for the mid/ late Holocene for the region, indicating an amelioration of climate towards moister conditions. Higher precipitation levels, without a major annual dry season that allowed marked forest expansion since late Holocene times were also inferred by Behling (1997) at Serra dos Campos Gerais for the last 1500 B.P. and by Behling (2007) at Serra do Araçatuba after 2000 B.P., both in Paraná state. For Santa Catarina (Behling 1995) and the Rio Grande do Sul highlands (Behling et al. 2001), the major Araucaria forest expansion occurred later than in Paraná (situated further north than Santa Catarina), i.e. during the last 1000 B.P., thus under modern climatic conditions.

Based on the increase of Weinmannia-type pollen frequencies, Behling et al. (2004) suggest a warmer phase during the little ice age (LIA) for the southern Brazilian highlands. This finding is consistent with our data, in which we found an increase of certain woody taxa that are characteristic of moister and warmer conditions, such as Weinmannia. An interpretation inferred from a lake sediment from São Paulo state indicates a warmer and probably wetter period for southeastern Brazil between 370 and 340 B.P., which fits into the LIA (Pessenda et al. 2010). The LIA is known as a period of cooling in Europe between about A.D. 1200 and 1700.

Considerable vegetational changes occurred due to ecosystem disturbance over the last 360 years, resulting in forest opening. The disturbance of the native forest in the Ciama region during the last centuries can be related to the activities of Portuguese settlers from the coast, who might have exploited the forest throughout the 17th and 18th centuries. Ecosystem disturbance has also taken place because of the construction of a road for timber transport by the company Ciama in the 1950s. By successive timber exploitation and burning, additional open areas were created, which under cattle grazing may have been converted into anthropogenic grassland (Klein 1981) formed by species from nearby Campos.

Palaeofires and implication for human occupation in southern Brazil

Charcoal particles were relatively rare during glacial times. Power et al. (2008) recorded the lowest fire occurrence during the glacial period under a cooler and drier-thanpresent global climate. The charcoal can be interpreted as a wind-blown intake from fire events across larger distances, assuming that natural fires were very unlikely in these highland environments during glacial periods. Local palaeofires could not be detected based on the concentration of charred particles, as the counted particles sizes $(5-150 \mu \mathrm{m})$ were mostly too small to give certainty about this. The counted sedimentary charcoal fragments (normally $<50 \mu \mathrm{m}$ ) indicate distant or regional fire events (Clark and Royall 1995; Carcaillet et al. 2001).

During the Holocene, fire events were very common in the region from ca. 10400 until 3600 cal. B.P. It is likely that Amerindians may have caused these fires. Prous and Fogaça (1999) provide evidence for human presence in Minas Gerais, central Brazil, at the end of the Pleistocene (between 12000 and 11000 B.P.). The authors also pointed out that human occupation in southern Brazil can be recorded since ca. 8000 B.P., when the Umbu and Humaitá cultures arrived. Available evidence suggests that fires of anthropogenic origin can be dated back to the beginning of the Holocene in Paraná state (Behling 1997) and to after 7400 B.P. in Rio Grande do Sul state (Behling et al. 2004). Prehistoric fires continued to be common during the late Holocene. However, it would be reasonable to interpret these fires in the Serra do Tabuleiro as being of anthropogenic origin during the late Holocene, as climate was moist in the early/mid-Holocene and more humid during the late Holocene.

Insights from the results for future conservation in the State Park Serra do Tabuleiro

The remaining areas of natural Campos at higher elevations of the State Park Serra do Tabuleiro will probably disappear in the future due to progressive forest expansion over Campos under the modern, humid climatic conditions (e.g. Hueck 1966; Lindman 1906; Rambo 1956a, b). Nonetheless, this biodiverse ecosystem can be maintained by human interference, such as the promotion of fire and grazing (e.g. Behling and Pillar 2007; Behling et al. 2007; Jeske-Pieruschka et al. 2010; Overbeck et al. 2005; Pillar 2003; Pillar and Vélez 2010). If fire and/or grazing by large grazers are not allowed, then the restricted areas of Campos in the park might be maintained by mowing (Fidelis et al. 2012).

Observations of Araucaria forest replacing Campos areas are also recorded by Hueck (1953) and Klein (1960), as well as by Oliveira and Pillar (2004). Furthermore, the first two authors notice that the Atlantic rainforest restricts both the Campos and the Araucaria forest in its ongoing vegetation succession. Here, we provide evidence for a progressive replacement of Campos and Araucaria forest by Atlantic rainforest in the southern Brazilian highlands if climate becomes warmer under the effects of global change. At present times, frequent frost during the winter months continues to limit the survival of tropical species on the highlands. However, if climate becomes drier and/or longer periods of drought become more frequent, both ecosystems, the Araucaria forest as well as the Atlantic rainforest, will show a hindered development due to water deficits. To sum up, the present landscape, shaped by a Campos-Araucaria forest mosaic on the southern Brazilian highlands, will be replaced by Atlantic rainforest under warmer climatic conditions. On 
the other hand, the forest ecosystem will retreat under drier climatic conditions. Hence, future climate changes will play a crucial role in vegetation composition and dynamics in the subtropical southern Brazilian highlands.

\section{Conclusions}

The pollen and charcoal record from the coastal mountain range of Serra do Tabuleiro reveals palaeoenvironmental changes in southern Brazil during the last 39720 в.P. The results indicate that a treeless landscape continues to dominate under a cold and dry climate throughout the last glacial period until 13470 cal. B.P. A climatic amelioration towards warmer and wetter conditions during the transition from the Pleistocene to the Holocene period provided adequate conditions for the initial colonization of the slopes by trees at about 10400 cal. B.P., with tropical species migrating from the lowland and the coast across the slopes. The proximity to the Atlantic Ocean could also have enhanced the migration of forest taxa from the northern regions to the south due to moderate and moister conditions at the coast. The Atlantic rainforest expanded three times, at the beginning of the Holocene, during the mid/late Holocene, and during the last centuries. The Araucaria forest expanded twice during the late Holocene, each time showing differences in floristic composition. The Atlantic rainforest began to develop during the early Holocene and expanded further during the midHolocene in the region. As its initial development and expansion is reported for the mid-Holocene in the highlands of Rio Grande do Sul state, located further south, the observations indicate that the Atlantic rainforest shifted from the north to more southerly regions. Therefore, the Serra do Tabuleiro can be seen as a migratory corridor for the tropical species. We concluded that, under the effects of global warming, the Atlantic rainforest will expand through migration of many tropical plant species into the southern regions of Brazil, replacing Araucaria forest and, if grazing and fire are suppressed, replacing the Campos in Araucaria-Campos mosaics on the highlands. The consequence would be a change of the entire southern Brazilian highland landscape.

\begin{abstract}
Acknowledgments The authors are grateful to Nele Jantz and Alessandra Fidelis for an English revision of the article. We also thank Patricio Moreno and one anonymous reviewer for valuable comments which helped to significantly improve the manuscript. Funding for the project was provided by the Deutsche Forschungsgemeinschaft (DFG) (BE 2116/9-1). Part of fieldwork expenses and radiocarbon dating were financially supported by Fundação de Apoio à Pesquisa Científica e Tecnológica do Estado de Santa Catarina (FAPESC) (Grant CON08857/2007-9) and by the Inter-American Institute for Global Change Research (IAI) CRN-2005 (U.S. NSF Grant GEO-0452325).
\end{abstract}

Open Access This article is distributed under the terms of the Creative Commons Attribution License which permits any use, distribution, and reproduction in any medium, provided the original author(s) and the source are credited.

\section{References}

Barros V, Gonzalez M, Liebmann B, Camilloni I (2000) Influence of the South Atlantic convergence zone and South Atlantic Sea surface temperature on interannual summer rainfall variability in Southeastern South America. Theor Appl Climatol 67:123-133

Behling H (1993) Untersuchungen zur spätpleistozänen und holozänen Vegetations- und Klimageschichte der tropischen Küstenwälder und der Araukarienwälder in Santa Catarina (Südbrasilien). Diss Bot 206. Cramer, Berlin/Stuttgart

Behling H (1995) Investigations into the Late Pleistocene and Holocene history of vegetation and climate in Santa Catarina (S Brazil). Veget Hist Archaeobot 4:127-152

Behling H (1997) Late quaternary vegetation, climate and fire history of the Araucaria forest and campos region from Serra Campos Gerais, Paraná State (South Brazil). Rev Palaeobot Palynol 97:109-121

Behling H (1998) Late quaternary vegetational and climatic changes in Brazil. Rev Palaeobot Palynol 99:143-156

Behling H (2002) South and southeast Brazilian grasslands during late quaternary times: a synthesis. Palaeogeogr Palaeoclimatol Palaeoecol 117:19-27

Behling H (2007) Late Quaternary vegetation, fire and climate dynamics of Serra do Araçatuba in the Atlantic coastal mountains of Paraná State, southern Brazil. Veget Hist Archaeobot 16:77-85

Behling H, Negrelle RRB (2001) Tropical rain forest and climate dynamics of the Atlantic lowland, southern Brazil, during the late quaternary. Quat Res 56:383-389

Behling H, Pillar VD (2007) Late Quaternary vegetation, biodiversity and fire dynamics on the southern Brazilian highland and their implication for conservation and management of modern Araucaria forest and grassland ecosystems. Phil Trans R Soc B 362:243-251

Behling H, Bauermann SG, Neves PCP (2001) Holocene environmental changes in the São Francisco de Paula region, southern Brazil. J South Am Earth Sci 14:631-639

Behling H, Pillar VD, Orlóci L, Bauermann SG (2004) Late Quaternary Araucaria forest, grassland (Campos), fire and climate dynamics, studied by high-resolution pollen, charcoal and multivariate analysis of the Cambará do Sul core in southern Brazil. Palaeogeogr Palaeoclimatol Palaeoecol 203:277-297

Behling H, Pillar VD, Müller SC, Overbeck GE (2007) LateHolocene fire history in a forest-grassland mosaic in southern Brazil: implications for conservation. Appl Veg Sci 10:81-90

Cancelli RR (2008) Palinologia de Asteraceae: morfologia polínica e suas implicações nos registros do Quaternário do Rio Grande do Sul. MSc Dissertation, Universidade Federal do Rio Grande do Sul, Instituto de Geociências

Carcaillet C, Bouvier M, Fréchette B, Larouche AC, Richard PJH (2001) Comparison of pollen-slide and sieving methods in lacustrine charcoal analyses for local and regional fire history. Holocene 11:467-476

Clark JS, Royall PD (1995) Particle-size evidence for source areas of charcoal accumulation in Late Holocene sediments of eastern North American lakes. Quat Res 43:80-89

Cordeiro SH, Lorscheitter ML (1994) Palynology of Lagoa dos Patos sediments, Rio Grande do Sul, Brazil. J Paleolimnol 10:35-42

Cruz FW Jr, Burns SJ, Karmann I, Sharp WD, Vuille M, Cardoso AO, Ferrari JA, Silva Dias PL, Viana O Jr (2005) Insolation-driven changes in atmospheric circulation over the past $116 \mathrm{ky}$ in subtropical Brazil. Nature 434:63-66

Cruz FW, Burns SJ, Karmann I, Sharp WD, Vuille M, Ferrari JA (2006) A stalagmite record of changes in atmospheric circulation and soil processes in the Brazilian subtropics during the Late Pleistocene. Quat Sci Rev 25: 2,749-2,761

Díaz AF, Studzinski CD, Mechoso CR (1998) Relationships between precipitation Anomalies in Uruguay and Southern Brazil and Sea 
surface temperature in the Pacific and Atlantic Oceans. J Climate $11: 251-271$

Faegri K, Iversen J (1989) Textbook of pollen analysis. Wiley, Chichester

Fidelis A, Blanco CC, Müller SC, Pillar VD, Pfadenhauer J (2012) Short-term changes caused by fire and mowing in Brazilian Campos grasslands with different long-term fire histories. J Veget Sci 23:552-562

Garreaud RD, Vuille M, Compagnucci R, Marengo J (2009) Presentday South American climate. Palaeogeogr Palaeoclimatol Palaeoecol 281:180-195

Grimm EC (1987) CONISS: a Fortran 77 program for stratigraphically constrained cluster analysis by the method of the incremental sum of squares. Comput Geosci 13:13-35

Grimm E (1991) Tilia Software. Illinois State Museum. Research and Collection Center. Springfield

Grimm AM, Ferraz SET, Gomes J (1998) Precipitation Anomalies in Southern Brazil associated with El Niño and La Niña Events. J Climate 11:2,863-2,880

Grimm AM, Barros VR, Doyle ME (2000) Climate variability in Southern South America associated with El Niño and La Niña Events. J Climate 13:35-58

Hueck K (1953) Distribuição e habitat natural do Pinheiro do Paraná (Araucaria angustifolia). Bol Fac Filos Cienc USP Bot 10:1-24

Hueck K (1966) Die Wälder Südamerikas. Fischer, Stuttgart

Jeske-Pieruschka V, Fidelis A, Bergamin RS, Vélez E, Behling H (2010) Araucaria forest dynamics in relation to fire frequency in southern Brazil based on fossil and modern pollen data. Rev Palaeobot Palynol 160:53-65

Jeske-Pieruschka V, Behling H (2012) Palaeoenvironmental history of the São Francisco de Paula region in southern Brazil during the late Quaternary inferred from the Rincão das Cabritas core. Holocene 22:1,251-1,262

Klein RM (1960) O aspecto dinâmico do pinheiro brasileiro. Sellowia $12: 17-44$

Klein RM (1962) Notas sobre algumas pesquisas fitosociológicas no sul do Brasil. Boletim Paranaense Geologia 6:17-28

Klein RM (1978) Mapa Fitogeográfico do Estado de Santa Catarina. Flora Ilustrada Catarinense

Klein RM (1981) Fisionomia, importância e recursos da vegetação do Parque Estadual da Serra do Tabuleiro. Sellowia 33:5-54

Leal MG, Lorscheitter ML (2007) Plant succession in a forest on the Lower Northeast Slope of Serra Geral, Rio Grande do Sul, and Holocene palaeoenvironments, Southern Brazil. Acta Bot Bras 21:1-10

Ledru M-P, Salgado-Labouriau ML, Lorscheitter ML (1998) Vegetation dynamics in southern and central Brazil during the last 10,000 year B.P. Rev Palaeobot Palynol 99:131-142

Ledru M-P, Mourguiart P, Riccomini C (2009) Related changes in biodiversity, insolation and climate in the Atlantic rainforest since the last Interglacial. Palaeogeogr Palaeoclimatol Palaeoecol 271:140-152

Leonhardt A, Lorscheitter ML (2010) The last 25,000 years in the Eastern Plateau of Southern Brazil according to Alpes de São Francisco record. J South Am Earth Sci 29:454-463

Lindman CAM (1906) A vegetação no Rio Grande do Sul. EDUSP/ Itatiaia, São Paulo

Lorscheitter ML (2003) Contribution to the Holocene history of Atlantic rain forest in the Rio Grande do Sul state, southern Brazil. Rev Mus Argent Cienc Nat 5:261-271

McCormac FG, Hogg AG, Blackwell PG, Buck CE, Higham TFG, Reimer PJ (2004) SHCAL04 southern hemisphere calibration, 0-11.0 Cal. kyear BP. Radiocarbon 46:1,087-1,092

Morellato LPC, Haddad CFB (2000) Introduction: the Brazilian Atlantic forest. Biotropica 32:786-792

Myers N, Mittermeier RA, Mittermeier CG, Da Fonseca GAB, Kent J (2000) Biodiversity hotspots for conservation priorities. Nature 403:853-858
Nimer E (1989) Climatologia do Brasil. Fundação Instituto Brasileiro de Geografia e Estatística, Rio de Janeiro

Oliveira JM, Pillar VD (2004) Vegetation dynamics on mosaics of Campos and Araucaria forest between 1974 and 1999 in Southern Brazil. Commun Ecol 5:197-202

Oliveira MAT, Lima GL, Duzzioni R, Paulino RB (2006) Avaliação de geomorfosítios e valorização abiótica de unidades de conservação: estudo de caso no Parque Estadual da Serra do Tabuleiro (SC). VI Simpósio Nacional de Geomorfologia/ Regional conference on Geomorphology

Oliveira MAT, Behling H, Pessenda LCR, Lima GL (2008) Stratigraphy of near-valley head quaternary deposits and evidence of climate-driven slope-channel processes in southern Brazilian highlands. Catena 75:77-92

Overbeck GE, Müller SC, Pillar VD, Pfadenhauer J (2005) Fine-scale post-fire dynamics in southern Brazilian subtropical grassland. J Veget Sci 16:655-664

Patterson WA, Edwards KJ, Maguire DJ (1987) Microscopic charcoal as a fossil indicator of fire. Quat Sci Rev 6:3-23

Pessenda LCR, Saia SEMG, Gouveia SEM, Ledru M-P, Sifeddine A, Amaral PGC, Bendassoli JA (2010) Last millennium environmental changes and climate inferences in the southeastern Atlantic forest, Brazil. An Acad Bras Cienc 82:717-729

Pillar VD (2003) Dinâmica da expansão florestal em mosaicos de floresta e campos no sul do Brasil. In: Claudino-Sales V (org) Ecossistemas Brasileiros: Manejo e Conservação. Expressão Gráfica e Editora, Fortaleza, pp 209-216

Pillar VD (2006) MULTIV Multivariate Exploratory Analysis, Randomization Testing and Bootstrap Resampling; User's Guide v. 2.5. UFRGS, Departamento de Ecologia, Porto Alegre. (Software and manual available from http://ecoqua.ecologia.ufrgs.br)

Pillar VD, Vélez E (2010) Extinção dos Campos Sulinos em Unidades de Conservação: um Fenômeno Natural ou um Problema Ético? Natureza Conservação 8:84-86

Power M, Marlon J, Ortiz N, Bartlein PJ, Harrison SP et al (2008) Changes in fire regimes since the last glacial maximum: an assessment based on a global synthesis and analysis of charcoal data. Clim Dyn 30:887-907

Prous A, Fogaça E (1999) Archaeology of the Pleistocene-Holocene boundary in Brazil. Quat Int 53(54):21-41

Rambo B (1956a) Der Regenwald am oberen Uruguay. Sellowia 7:183-234

Rambo B (1956b) A Flora Fanerogâmica dos Aparados Riograndenses. Sellowia 7:235-298

Reimer PJ, Baillie MGL, Bard E, Bayliss A, Beck JW, Bertrand C, Blackwell PG, Buck CE, Burr G, Cutler KB, Damon PE, Edwards RL, Fairbanks RG, Friedrich M, Guilderson TP, Hogg AG, Hughen KA, Kromer B, McCormac FG, Manning S, Ramsey CB, Reimer RW, Remmele S, Southon JR, Stuiver M, Talamo S, Taylor FW, Van der Plicht J, Weyhenmeyer CE (2004) INTCAL04 terrestrial radiocarbon age calibration, 0-26 cal. k year BP. Radiocarbon 46:1,029-1,058

Roth L, Lorscheitter ML (1993) Palynology of a bog in Parque Nacional de Aparados da Serra, East Plateau of Rio Grande do Sul Brazil. Quat S Am Antarct Pen 8:39-69

Silva LCR, Anand M, Oliveira JM, Pillar VD (2009) Past century changes in Araucaria angustifolia (bertol.) Kuntze water use efficiency and growth in forest and grassland ecosystems of southern Brazil: implications for forest expansion. Glob Change Biol 15:2,387-2,396

Stockmarr J (1971) Tablets with spores used in absolute pollen analysis. Pollen Spores 13:615-621

Stuiver M, Reimer PJ (1993) Extended ${ }^{14} \mathrm{C}$ data base and revised CALIB radiocarbon calibration program. Radiocarbon 35:215-230

Tabarelli M, Pinto LP, Silva JMC, Hirota M, Bedê L (2005) Challenges and opportunities for biodiversity conservation in the Brazilian Atlantic forest. Conserv Biol 19:695-700 